\title{
Correlation of AGTH and MSH in man
}

\author{
K. ABE \\ 1st Department of Internal Medicine, Faculty of Medicine, University of Tokyo, Tokyo.
}

A radioimmunoassay for $\alpha$-MSH has been developed and this hormone has been identified in human pituitaries and the tumors of patients with the ectopic ACTH syndrome. However, $\alpha$-MSH accounted for only a small percentage of the total melanocyte stimulating activity of these tissues as determined by the MSH bioassay using the in vitro frog skin system. $\beta$-MSH radioimmunoassay has also been developed and utilized in conjunction with the MSH bioassay. It was found that most of the biologic MSH activity of the plasma and tissues could be accounted for by $\beta$-MSH. These data indicate that the main pigmentary hormone in man is $\beta$ - MSH.

Plasma $\beta$-MSH was found to be $20-110 \mathrm{pg} / \mathrm{ml}$ in normal subjects. Metyrapone increased and dexamethasone decreased plasma $\beta$-MSH levels. In 10 cases of untreated Addison's disease, plasma $\beta$-MSH levels were greatly elevated, ranging $266-1480 \mathrm{pg} / \mathrm{ml}$ with a mean of $797 \mathrm{pg} / \mathrm{ml}$. In contrast, plasma $\beta$-MSH values in 10 well controled addisonian patients were all within normal range. Plasma $\beta$-MSH was moderately elevated in 3 out of 4 patients with congenital adrenal hyperplasia $(120-190 \mathrm{pg} / \mathrm{ml})$. During treatment with glucocorticoids, plasma $\beta$-MSH was found to be low normal. In 9 patients with hypopituitarism, plasma $\beta$-MSH was low, ranging from a negligible level to $46 \mathrm{pg} /$ $\mathrm{ml}$ with a mean of $26 \mathrm{pg} / \mathrm{ml}$. In 11 patients with untreated Cushing's syndrome due to pituitary ACTH excess (Cushing's disease), plasma $\beta$-MSH was moderately elevated. In 9 patients who had developed pituitary tumors and hyperpigmentation following adrenalectomy for Cushing's disease, plasma $\beta$-MSH levels were extremely high, with a mean value of $4335 \mathrm{pg} / \mathrm{ml}$. However, 12 patients who did not develop pituitary tumors after adrenalectomy had a mean value of $365 \mathrm{pg} / \mathrm{ml}$. In 10 patients with Cushing's syndrome due to ectopic ACTH, plasma $\beta$-MSH was elevated, ranging $83-650 \mathrm{pg} / \mathrm{ml}$ with a mean of $341 \mathrm{pg} / \mathrm{ml}$. In patients with Cushing's syndrome due to adrenal tumor, plasma $\beta$-MSH was subnormal. Plasma $\beta$-MSH was measured in 8 patients undergone hysterectomy. In all cases plasma $\beta$-MSH was found to rise during surgery.

These data indicate that $\beta$-MSH was found to be elevated in the plasma of those cases whose plasma ACTH was known to be elevated and that plasma $\beta$-MSH was low when plasma ACTH was known to be low. In order to confirm these observations, plasma $\beta$-MSH and ACTH were measured in the same samples. For AGTH determinations Lipscomb and Nelson's bioassay method was employed. There existed a significant positive correlation between the levels of plasma $\beta-\mathrm{MSH}$ and ACTH. In the same extract of tumors from 15 patients with the ectopic ACTH syndrome, a high degree of positive correlation was also found between the concentrations of $\beta$-MSH and ACTH. These 
data suggest that the biosynthesis of $\beta$-MSH is closely related to that of ACTH.

These high correlations of $\beta-\mathrm{MSH}$ and ACTH are not the problem of the assay itself, because ACTH and many of its fragments did not cross-react in this radioimmunoassay system in any significant degree and the plasma samples from a normal subject who had received a large amount of pure ACTH did not show any significant increase in the plasma $\beta$-MSH levels.

It can be concluded that the regulation of $\beta-\mathrm{MSH}$ is controled by the same mechanism by which ACTH is regulated and the synthesis of $\beta-\mathrm{MSH}$ is closely linked to that of ACTH.

(These data were published in J. Clin. Endocr., 27: 46, 1967; J. Clin. Invest., 46: 1609, 1967; land J. Glin. Invest., 48: 1580, 1969.)

(See pp. 856 862) 


\title{
シンポジゥム III ホルモンの相互関係
}

\section{下 垂 体 \\ 1. $\mathrm{ACTH}$ と $\mathrm{MSH}$}

\author{
東大第一内科
}

阿部

薫

下垂体ホルモンである ACTH と MSH は互いにその構造が以ており, ために ACTH は弱いながら $\mathrm{MSH}$ 作用があり，また MSH にはわずかではあるが AGTH 作用がある. そのため従来広く用いられ ていた生物学的測定法ではての両者を完全に分離測定することは困難であつた。. 清水らは Addison 病, Cushing 病で両側の副腎摘除をうけた症例などについて検討を加え，てれらの患者血中には AGTH 以外 に MSH 作用を有する物質が増加しているととを証明しているが，（J. Clin. Endocr., $25: 984,1965$ ) し かしてれが何であるかは明らかにされていない。

私はアメリカVanderbilt 大学に 5 年間滞在中, Liddle 教授の下で, $\alpha$-MSH と $\beta$-MSH の radioimmunoassay を確立し，乙れに AGTH と MSH の生物学的測定を加えることにより，AGTH と MSH の相互関係につき検討したので，ててで得られた成績につき述べてみたい.

\section{ACTH と MSH の構造}

MSH そは $\alpha$-MSH と $\beta$-MSH の 2 種類がある.

図1亿示したように, ACTH は39ケのアミノ酸が直 線的につながつたもので, $\alpha$-MSH はての ACTH の 1 から13の部分と全く同じアミノ酸構成を有している が，ただ 1 の位置にアセチル基，13の位置にアミノ基 がついている. ヒトの $\beta$-MSH は22 ケのアミノ酸が 直線的につながつたものであるが，ACTH の 4-10の 部分の 7 ケのアミノ酸配列は $\beta$-MSH の11-17の部分 と全く同じアミノ酸構成を有している. このように構 造上共通の部分のあるととが, ACTH に MSH 作用 があり,また MSH に ACTH 作用のある理由と考

Fig. 1. Structures of ACTH and MSH.

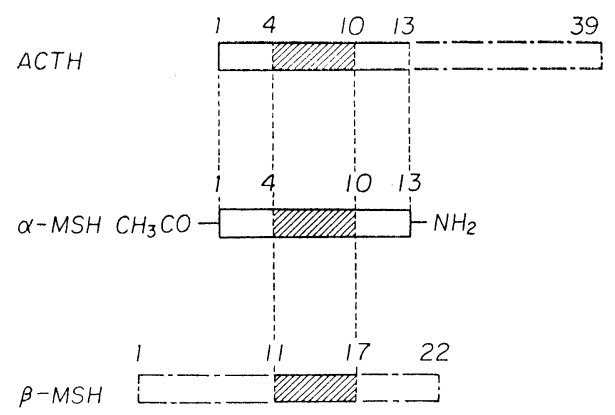
えられており，またてれがての両者を分離，測定するうえでの困䧼をもたらしている．

\section{II. $\alpha-\mathrm{MSH}$ の radioimmunoassay}

ヒト下垂体について得られた $\alpha$-MSH の radioimmunoassay の成績を表 1 亿示した. total MSH activityは，鎮目らの方法により測定した。表1からも明らかなように，ヒトの下垂体では $\alpha$-MSH は total MSH activityのわずか $1 〜 3 \%$ 占めるにすずない, さらに Addison 病, 副腎摘除をうけた Cushing 病 (Nelson 症候群) の患者などで, 高度の色素沈着を呈した症例において血中 $\alpha$-MSH を測定しても, てれ は検出されず，乙のような成績から $\alpha-\mathrm{MSH}$ はヒトにおいて MSH としてあまり重要な作用を持たないと 考えられる。 
表 1 ヒト下垂体における $\alpha$-MSH

\begin{tabular}{l|c|c|c}
\hline \hline & $\begin{array}{c}\text { Concentra- } \\
\text { tion of } \\
\alpha \text {-MSH } \\
(\mathrm{ng} / \mathrm{mg})\end{array}$ & $\begin{array}{c}\text { Total } \\
\text { MSH } \\
\text { activity } \\
(\mathrm{ng} / \mathrm{mg})\end{array}$ & $\begin{array}{c}\alpha \text {-MSH } \\
(\%)\end{array}$ \\
\hline Pituitary 1 & 1.1 & 42 & 3 \\
Pituitary 2 & 0.7 & 62 & 1 \\
Pituitary 3 & 0.7 & 42 & 2 \\
Pituitary 4 & 0.4 & 33 & 1 \\
\hline
\end{tabular}

Total MSH activity は合成 $\alpha-\mathrm{MSH}$ を $\mathrm{MSH}$ の生物学的測定の standard として用いての ngにより示した,

\section{III. $\beta$-MSH $の$ radioimmunoassay}

次いで $\beta$-MSH の radioimmunoassay を確立した が, “Bound”を “Free”の分離には paper chromatoelectrophoresis を用い, 乙の実例を図 2 亿示した. この方法は $1 \mathrm{pg} の \beta-\mathrm{MSH}$ が検出可能であつた.

Radioimmunoassay そおいては sensitivity ととも に specificity が重要である. これを検討するために $\alpha$-MSH, ACTH および ACTH の各種 fragments を 用い, この $\beta$-MSH radioimmunoassay 系における 交叉反応を検討した。図3からも明らかなように， $\alpha$-MSH, 各種の ACTH fragments はなんら有意の交

叉反応を示さず，ただブタの合成 ACTH および精製されたヒト ACTH のみが反応を示した. しかし $\beta$ MSH と同じ程度の反応を示すには重量にして約3000倍の ACTH が心要であり，かかる大量の AGTH が ヒトの血申に存在するとは考えられず，ACTH がこの radioimmunoassay を妨害する可能性はありえな い.さらに多くの検体について AGTH の生物学的測定を併用し，かかる可能性のないてとをたしかめた.

さらに測定しているものが $\beta$-MSH である証拠を固めるために, 各検体について dose response を求め, てれがいかに standard である合成ヒト $\beta$-MSH で得られた曲線と平行であるかを検討した. ての結果を 図 4 に示したが，ヒト下垂体，異所性 AGTH 産生腫瘍，色素沈着を示す患者および正常人血液について

Fig. 2. Chromatoelectrophoretsic mobility of $\beta_{\mathrm{h}}-\mathrm{MSH}-{ }^{131} \mathrm{I}$. The location of labeled hormone at the completion of chromatoelectrophoresis is represented on the abscissa. The quantity of radioactivity is represented on the ordinate. The first scan shows that, with normal guinea pig serum, $\beta_{\mathrm{h}}-\mathrm{MSH}^{131}$ I was "free" (F) and remained at the origin. Tbe second scan shows that, when incubated with the antiserum, most of the $\beta_{\mathrm{h}}-\mathrm{MSH}^{131} \mathrm{I}$ was "bouud" (B) and migrated with the globulin fraction. The third and fourth scans show that the addition of progressively greater quantities of unlabeled $\beta_{\mathrm{h}}-\mathrm{MSH}(0.05 \mathrm{ng}, 0.2 \mathrm{ng})$ to the mixture resulted in progressively greater displacement of ranioactivity from the "bound" peak to the "free" peak and a decrease in B/F ratio.
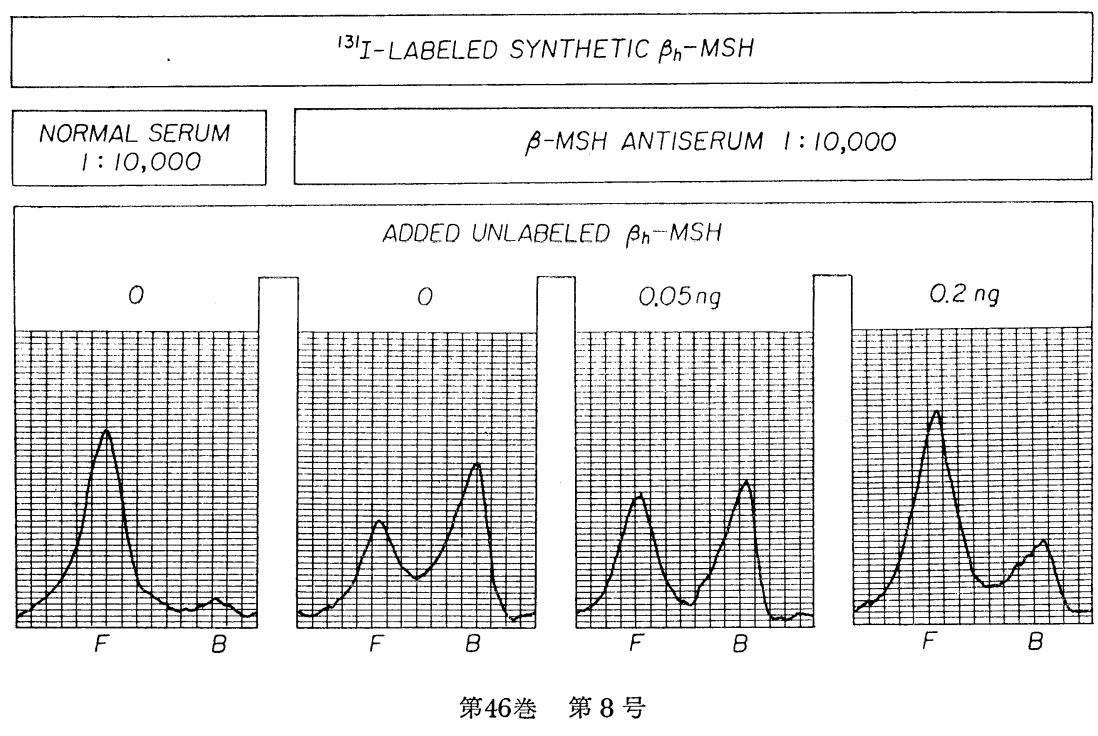
dose response curve を求めてみると，いずれも standard の $\beta$-MSH と平行の dose response を示した. 以上のような所見から，ての radioimmunoassay に より測定されているものは $\beta-\mathrm{MSH}$ であると結論さ れた。

Fig. 5 には正常人および各種疾患患者で測定した血 中 $\beta-\mathrm{MSH}$ 中の成績を示した. 正常值は $20 \sim 110 \mu \mathrm{g} / \mathrm{ml}$ であつた. 未治療の Addison 病では高值を示し (266 $-1480 \mu \mathrm{g} / \mathrm{ml}$, 平均 $797 \mu \mathrm{g} / \mathrm{ml})$, glucocorticoids 治療で 正常範囲に低下している.

未治療の congenital adrenal hyperplasia の患者 4 例中 3 例では高值を示したが $(120-190 \mathrm{pg} / \mathrm{ml})$ ，乙 れも glucocorticoids 治療により低下している.下垂 体機能低下症ではいずれも低い值を示した（平均 26 $\mathrm{pg} / \mathrm{ml})$ ，かかる成績はこのような疾患における血中 $\beta-\mathrm{MSH}$ の変化が，血中 ACTH と全く同じ傾向を持つととを示している.

Cushing 症候群は下垂体の ACTH 過剩による Gushing 病と, 異所性 ACTH 産生腫瘍によるもの,

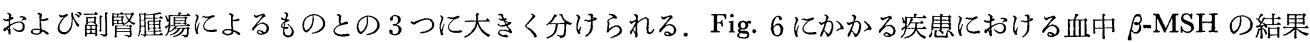
を示したが，下垂体の ACTH 過剰および異所性 ACTH 産生腫瘍の患者では ACTH のように血中 $\beta$ MSH はいずれも高く, 副腎腫瘍の患者では一般に AGTH は分泌が抑制されて低值を示すが，血中 $\beta$ MSH も同じく低值を示した.

下垂体性 Cushing 症候群 (Cushing 病) の患者で副腎摘除を受けたあとに, 時に下垂体腫瘍，高度の色 素沈着を呈することがある. かかる場合には血中 ACTH は異常な高值を呈することが知られているが，乙 のような症例で $\beta$-MSH を測定してみると Fig. 7 に示したように，やはり非常に高い值を示し，てとに下 垂体腫瘍を呈した例では高値を示した。(4335 $\mu \mathrm{g} / \mathrm{ml})$. しかし同じ副腎摘除をうけた症例でも，下垂体腫瘍 を呈しなかつた例では， $\beta-\mathrm{MSH}$ の值はさほど高くなかつた（平均 $365 \mathrm{pg} / \mathrm{ml}$ ).

血中 ACTH は外科的手術のような stress により上昇するてとが知られている. 血中 $\beta$-MSH, 血中 17OHCS を子宮摘除をうけた 8 例につき，その手術前と，手術開始 1 時間後に測定すると，Fig. 8 に示した

Fig. 4. Radioimmunoasiay of $\beta-\mathrm{MSH}$ in human pituitary glands, in tumors from patients with the ectopic ACTH syndrome, in plasma from hyperpigmented patients, and in plasma of normal subjects.

$$
\begin{array}{ccc}
\text { SYNTHETIC } & \text { PITUITARY } & \text { TUMOR } \\
\beta_{h}-\text { MSH } & \text { TISSUE } & \text { TISSUE }
\end{array}
$$
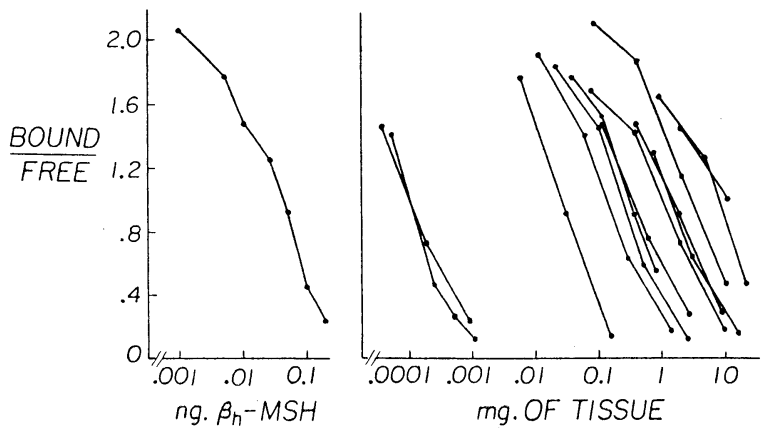

第 46 巻 第 8 号
PLASMA

HYPERPIGMENTED

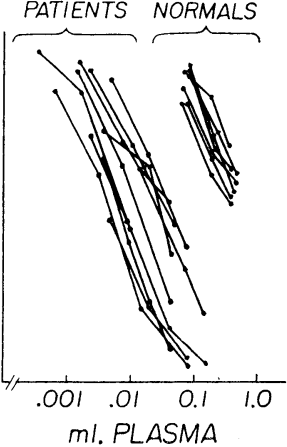


Fig. 5. Plasma $\beta$-MSH in normal subjects and patients with Addison's disease, congenital adrenal hyperplasia, or hypopituitarism. The horizontal lines represent the means of various groups.

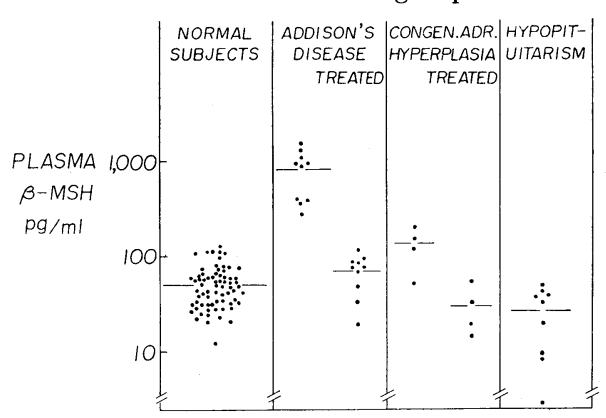

Fig. 7. Plasma $\beta$-MSH in Cushing's disease (postadrenalectomy). For comparison, the data for untreated Cushing's disease in Fig. 6 are reproduced here. $\triangle=$ patients who had previausly undergone pituitary irradiation.

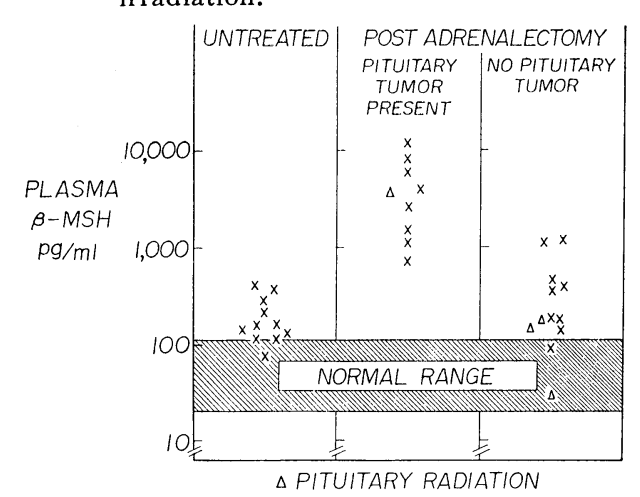

ように，全例に $\beta$-MSH および血中 17-OHCS の上 昇が認められた。なお手術前に正常値より高い $\beta-\mathrm{MSH}$ の值を呈した 2 例は, いずれも高い 17-OHCS の值を 有していた。

血中 ACTH は cortisol 生合成の阻害剤である metyrapone 投与により上昇し, dexamethasone 投 与により低下する. $0.75 \mathrm{~g} の$ metyapone を 4 時間お きに1日投与，また $1 \mathrm{mg} の$ dexamethasone を 6 時 間おきに 1 日投与して，その前後で血中 $\beta$-MSH を 測定した. Fig. 9 に示したように血中 $\beta$-MSH は metyrapene により上昇し, dexamethasone により抑制 された。

以上のような血中 $\beta-\mathrm{MSH}$ の測定成績をみてみる
Fig. 6. Plasma $\beta$-MSH in untreated Cushing's syndrome due to pituitary ACTH excess, ectopic ACTH-MSH syndrome, and adrenal tumor.

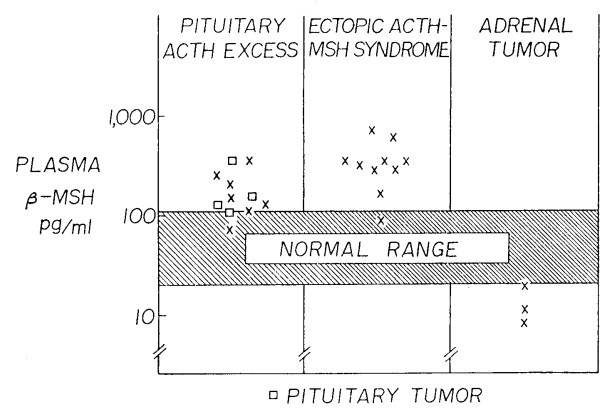

Fig. 8. Plasma $\beta$-MSH in response to surgical stress. Blood was drawn for plasma $\beta$ MSH and 17-OHCS assays $1 \mathrm{hr}$ before surgery and $1 \mathrm{hr}$ after the laparotomy incision.

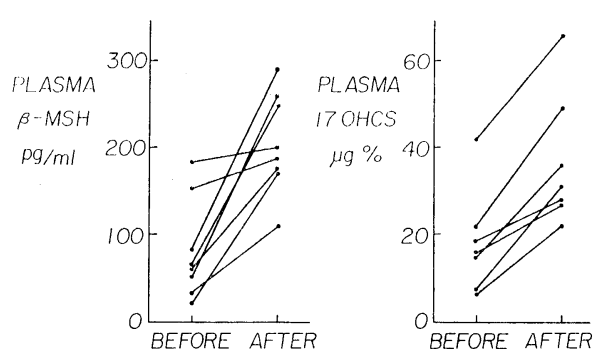

Fig. 9. Left : Plasma $\beta$-MSH in normal subjects before and after treatment with metyrapone. Blood was drawn at 6 a.m. just before the first dose of metyrapone $(0.75$ g every $4 \mathrm{hr}$ ) and again at $6 \mathrm{a} . \mathrm{m}$. on the following day. Right : Plasma $\beta$-MSH in normal subjects before and after treatment with dexamethasone. Blood was drawn at 6 a.m. before the first dose of dexamethasone ( $1 \mathrm{mg}$ every $6 \mathrm{hr}$ ) and again at 6 a.m. on the following day.

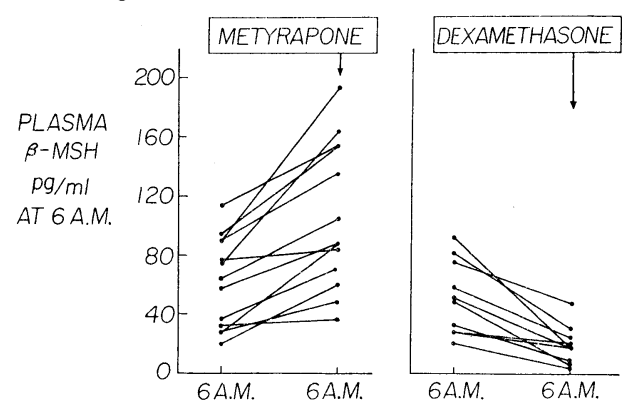


表 2 Addison 病, Nelson 症候群, 異所性 AGTH 産生腫瘄患者の血中および異所性 $\mathrm{ACTH}$ 産生腫湯中の $\beta$-MSH と生物学的 $\mathrm{MSH}$ 活性

(血 液)

\begin{tabular}{c|c|c|c}
\hline \hline Disease & Patient & $\begin{array}{c}\text { Immunologic } \\
\beta-\text { MSH }\end{array}$ & $\begin{array}{c}\text { Biologic } \\
\text { MSH } \\
\text { activity* }\end{array}$ \\
\hline Addison's & J . F. & 0.5 & 0.5 \\
disease & G.S. . & 0.8 & 0.9 \\
& J.R. & 1.1 & 0.6 \\
Nelson's & A.W. & 0.7 & 0.6 \\
syndrome & E.K. & 3.7 & 1.7 \\
& H.R. & 3.9 & 4.3 \\
& E.B. & 2.7 & 5.0 \\
& M.J. & 5.2 & 3.8 \\
& G.K. & 6.0 & 2.0 \\
& B.H. & 1.1 & 0.7 \\
Ectopic ACTH & M. J . & 5.1 & 3.4 \\
syndrome & J.L. & 0.9 & 0.3 \\
\hline
\end{tabular}

*Biologic MSH activity expressed as nanograms of synthetic $\beta_{\mathrm{h}}-\mathrm{MSH}$.
（腫 痬）

\begin{tabular}{c|c|c}
\hline Patient & $\begin{array}{c}\text { Immunologic } \\
\beta \text {-MSH }\end{array}$ & $\begin{array}{c}\text { Biologic } \\
\text { MSH } \\
\text { activity* }\end{array}$ \\
\hline G.O. & 25 & $\mathrm{ng} / \mathrm{g}$ \\
I.P. & 30 & 34 \\
D.H. & 258 & 34 \\
J.N. & 126 & 210 \\
J.S. & 14 & 90 \\
L.G. & 6 & 18 \\
V.B. & 102 & 18 \\
D.S. & 1600 & 402 \\
G.W. & 25 & 1860 \\
J.G. & 108 & 96 \\
F.T. & 3 & 216 \\
\hline
\end{tabular}

と, 血中 ACTH が高い值を示す条件下では血中 $\beta$ - MSH も高い值を示し, 血中 ACTH が低い值を示 す場合には，血中 $\beta-\mathrm{MSH}$ も低い值を示している。すすおち ACTH と $\beta-\mathrm{MSH}$ は全く同じ機序により分 泌されているととがわかつた.

こてで血中 $\beta$-MSH の値を生物学的測定で得られたbiologic MSH activity と比較すると, 表 2 に示した ように, 各種疾患患者の血中生物学的 MSH 活性は，ほとんどが $\beta$-MSH により説明され，さらに異所性 ACTH 産生腫瘍中の MSH 活性もほぽ $\beta$-MSH によると結論された。 てのような所見と, 前に述べた $\alpha$ $\mathrm{MSH}$ の成績とを考え併せてみると，ヒトにおける主な MSH は $\beta$ - MSH であるといえる.

ヒトにおける主な MSH が $\beta$-MSH であるなら， 血中 $\beta$-MSH の值と, 色素沈着の程度との関連は非 常に興味ある問題である。そこで下垂体一副腎系疾患 患者における色素沈着，すなわち“addisonian hyper-

Fig. 10. Correlation of clinical hyperpigmentation with the concentration of $\beta$-MSH in the plasma.

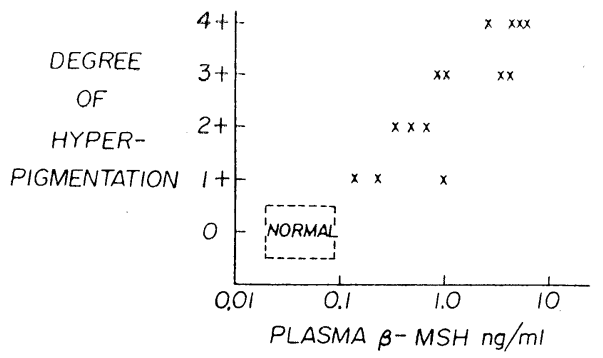

Fig. 11. Correlation of plasma $\beta$-MSH and ACTH in Addison's disease, Cushing's disease (postadrenalectomy) and the ectopic ACTH-MSH syndrome. Highly purified human ACTH was used as a standard in the ACTH bioassay.

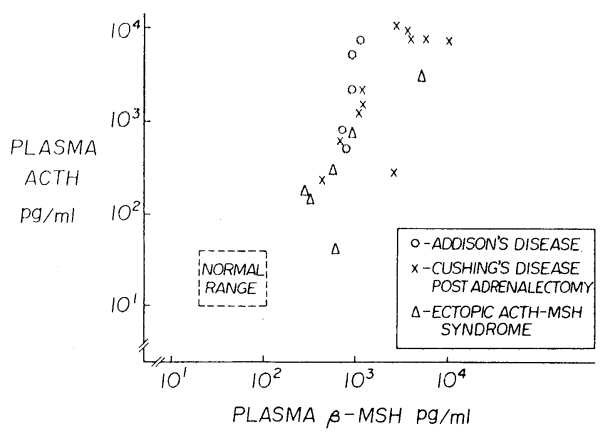


pigmentation”の程度と血中 $\beta$-MSH の值とを比してみた. 血中 $\beta$-MSH の值を全く知らない専門家が, 色素沈着の程度を 1 十から 4 +に分類し，乙れと血中 $\beta$-MSH の值とを対比したものをFig. 10に示した. と れからも明らかなように，色素沈着の程度と血中 $\beta-\mathrm{MSH}$ の值との間に深い相関が認められ，血中 $\beta-M S H$ の上昇が色素沈着の原因であるととを示している.

\section{IV $\beta$-MSH $亡 \mathbf{A C T H}$}

同一検体について血中 $\beta$-MSH と ACTH とを測定した. ACTH の測定には Lipscomb \& Nelson の 生物学的方法を用いた，Fig.11に示したように，血中 $\beta$-MSH と AGTH の值は深い相関を示した。（r= $7.0, \mathrm{p}<0.001)$ 。すなわち血中 AGTH が上昇するような条件の下では, 血中 $\beta$-MSH も上昇し, 一般的に 血中 ACTH の值が高ければ高いほど, 血中 $\beta$-MSH も高い值を示した.

さらに15例の異所性 AGTH 産生腫瘍について $\beta$-MSH を測定してみると, 全例に $\beta$-MSH が証明され, Fig. 12に示すように, 腫煌中の ACTH 含有量が多いほど $\beta$-MSH の含有量も高く, ての両者は高度の相

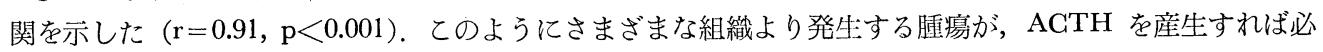
らず $\beta$-MSH も産生するというととは, ACTH と $\beta$-MSH がその分泌のみならず，その生合成の過程に

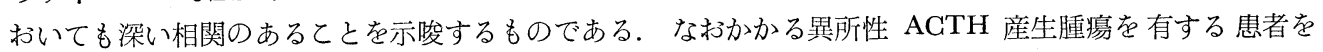
Liddle らは the ectopic ACTH syndrome と名づけ，てれが広く受け入れられているが，われわれはか かる症候群をむしろ the ectopic AGTH-MSH syndrome とよぶべきであると主張しており, Liddle らは この名称をすでに使いはじめている.

てのように ACTH と $\beta-\mathrm{MSH}$ は, その分泌, 生合成の過程において深い相関のあるてとは明らかであ るが，しかしとの $\beta$-MSH の radioimmunoassay が ACTH の代謝産物と交叉反応を示すために，ACTH が高いような場合に $\beta$-MSH も高い值を示すので はないかという疑問がおてる。すずに AGTH およ びいろいろな ACTH の fragments はこの $\beta$-MSH の radioimmnoassay 系揸いて, 有意の交叉反応 のないととを明らかにしたが，さらに正常人に高度

Fig. 12. Correlation of $\beta$-MSH and AGTH in tumors from patients with the ectopic ACTH-MSH syndrome. ACTH and $\beta$-MSH are plotted in picograms per milligram of wet tissue. Highly purified human ACTH was used as a standard in the ACTH bioassay.

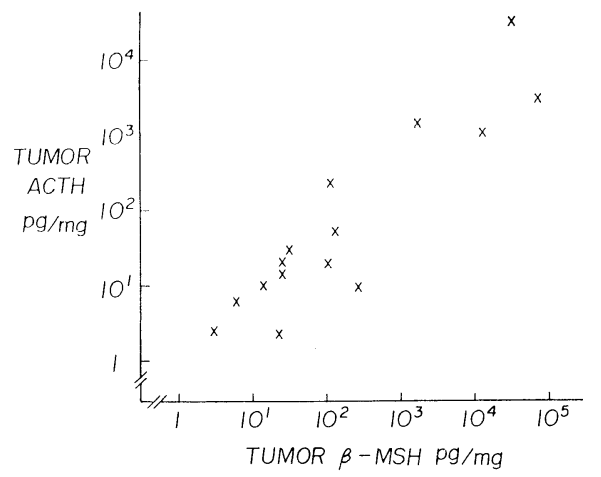

Fig. 13. ACTH infusion study. 1mg of highly purified human ACTH was injected intravenously into a normal subject at time 0. Blood was drawn from the opposite arm at the times indicated on the abscissa. The concentrations of $\beta$ $\mathrm{MSH}$ and ACTH found in the subject's plasma at various time intervals are plotted on the ordinate (log scale). A sample of the injected ACTH was used as a standard for the ACTH bioassay.

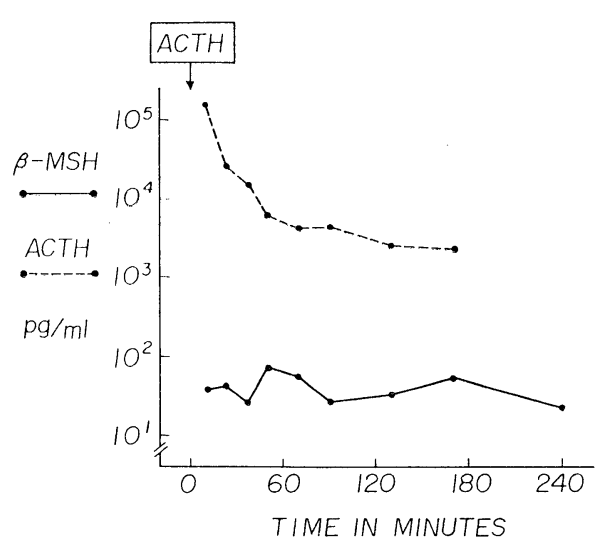


そ精製されたヒト AGTH $1 \mathrm{mg}$ を静注して, 経時的に採血し, 血中 $\beta$-MSH と AGTH を測定した. この 結果をFig.13に示したが，AGTH は非常に高い值より次第に低下して来るか，ての間血中 $\beta$-MSH は常に 正常範囲に止まつていた。 てのような成績から, 測定された $\beta$-MSH は AGTH の代謝産物ではないとい うことができる。

以上まとめてみると，ヒトにおける主な MSH は $\beta$-MSH であり，その分泌機序は AGTH と同じよう な機序により支配されており，その生合成は ACTH の生合成の機序と非常に密接な関連を有している.

かかる相関がいかなる意味を有しているかは非常に興味ある問題である. ACTH の分泌，合成の機序に MSH が重要な役割をはたしているという可能性も考えられるし，また Proinsulin から insulin が出来る ように, ACTH と MSH がはじめは長い1本の polypeptide で, てれが切れて, ACTH と MSH に分 かれるという可能性も考光られる. しかしてのような問題については今日まだ明らかでなく，かかる方面の

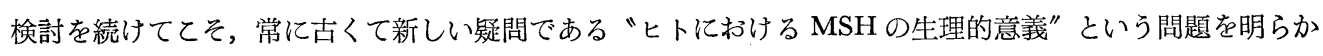
にするととができるものと考光られる。

（なおててに発表した成績はすべて J. Clin. Endocr., 27 : 46, 1967, J. Clin. Invest., 46: 1609, 1967, J. Clin. Invest., $48: 1580,1969$, 飞発表したあのである)

追 加

後葉ホルモンとカテコールアミン

阪大第 3 内科

矢 野 $三$ 郎
小 谷

最近, 後葉ホルモンとカテコールアミンとの相関が注目されている. 本稿では著者らが数年来, 実験を行 なつてきたカテコールアミンの末梢作用におよぼす後葉ホルモンの影響について述べるととにしたい.まず 第一にカテコールアミンの平滑筋作用におよぽす後葉ホルモンの影響について検討した結果, 家鬼大動脈片 を使用する in vitro の実験において，Oxytocin およびその誘導体は Norepinephrine の収縮作用を阻害 するととが認められた。てれに反して Lys-Vasopressin (LVP) はほとんど阻害作用を示さなかつた。つい で $\beta$ 一受容体刺载作用と考えられている Epinephrine のモルモット気管片驰緩作用におよぼす Oxytocin の 影響を検討した結果，家鬼大動眽片と同様の阻害効果か認められた。しかも上述の如きOxytocin の阻害 作用はカテコールアミンに対して特異的であつて, Angiotensin, Histamine, Acetylcholine の作用に対し ては全く影響がなかつた。

以上の実験の結果, Oxytocin はカテコールアミンの平滑笳に対する作用を $\alpha$-受容体刺戟作用も $\beta$-受容 体刺载作用もともに阻害するというととが in vitro で明らかにされた。

第 2 亿各種条件下のラットにわいて血嶈中 FFA 值にわよぼす後葉ホルモンの影響からカテコールアミン との関係について検討を加えた．正常ラットに LVP (IU) を投与すると30分後血漿中 FFA 值は明らかに 減少した。しかし Oxytocin 投与では影響が喼められなかつた。 24時間絶食ラットでは LVP による FFA 值の低下がさらに著明であつた。乙の場合には Oxytocin 投与でも軽度の低下作用が認められた。つぎに 24時間脱水ラットについて検討した結果，ての場合 LVP の FFA 低下作用は全く認められなかつた。す なわち, 内因性の Vasopressin が分泌されている条件下では LVP 投与の影響が認め難いと考えられる結 果を得た。なお，てのような条件下でもInsulin を投与すると明らかに FFAの低下作用が認められた。以 上のような LVP の血墏中 FFA 低下作用の機序として平滑筋におけると同様, カテコールアミン作用阻害 が考光られるので, Adrenergic blocking agents 前処置のラットにおける LVP の効果について検討を加 